\title{
A történelmi tudat fejlesztésének jelentősége és problémái
}

\section{Harcba szállunk-e az „intellektuális alvilággal”?}

Az „intellektuális alvilág” kifejezést Kosáry Domokos használta azokra a félmúvelt, gyakran elóitéletes véleményvezérekre, akik történelmi igazságokat nyilatkoztatnak ki alapvetóen szaktudományos kérdésekben is, és akik bele akarják fojtani a szót a velük vitatkozókba. ${ }^{1}$ Ez az agresszív, közgondolkodást romboló jelenség manapság még otrombábban tör utat magának világszerte. Egyoldalúan konstruált és egymással élesen szemben álló múltképek kezdik eluralni a közbeszédet, a médiát és a mindennapi gondolkodást. Kérdés, hogy a történelemoktatás miként reagál ezekre a kritikus történelmi gondolkodást és a történettudomány egészét érintó kihívásokra.

A hhoz, hogy az iskola hatékonyabb szerepet tudjon betölteni a történelmi közgondolkodás alakításában, szükség lehet a történelemtanulás általános céljainak újragondolására is. Erre történtek már kísérletek, ilyen volt például az a kerekasztal-beszélgetés, amelyen hazai történészek, történelemdidaktikusok és gyakorló történelemtanárok vitatták meg a jelenlegi gyakorlat problémáit (Kojanitz, 2018). E tanulmányban elöször a mostanra kialakult helyzet lehetséges okaival és következményeivel foglalkozom, utána pedig olyan értelmezési kereteket és szempontrendszereket mutatok be, amelyek segítségül szolgálhatnak a történelemtanítás szerepéről és céljáról szóló további vitákhoz. Ehhez egyebek mellett felhasználom Peter Seixas (2016) a történelemtanítás társadalmi szerepéről készített modelljét, összehasonlítom Jörn Rüsen (2006), Stéphane Lévesque (2018) és Andreas Körber (2018) elméleti konstrukcióit a történelmi tudat összetevőiről, szintjeiről és fejlődéséről, és foglalkozom azokkal a gondolatokkal is, amelyeket Peter J. Lee fogalmazott meg a történelemtanítás autonómiájának fontosságáról (Bereta da Silva, 2012).

\section{A történettudomány háttérbe szorulása a történelmi vitákban}

Az elmúlt évtizedekben az egész világon jelentősen megváltozott az emberek viszonyulása a történelmi vitákhoz és a történettudomány képviselöihez (de Groot, 2009). A különböző történelmi események vagy személyek megítélése egyre inkább hitbéli

1 Erről Hermann Róbert (2019) beszélt az egyik vele készült interjúban. 
vagy politikai kérdéssé kezd válni, s a közösségi oldalalakon és a médiákban a témát kutató történészek állításai gyakran elvesznek a „szelektíven tájékozódó” fanatikusok és a naiv érdeklődők hozzászólásainak özönében. Sőt sok esetben tudatos hangulatkeltés is folyik a leegyszerüsítő vagy hamis állításokat megcáfoló történészekkel szemben. ${ }^{2}$ E helyzet kialakulásához valószínüleg egyszerre több ok vezetett. Itt most ezek közül négyre térek ki: a korábban elnyomott társadalmi csoportok történelmi öntudatra ébredése; az infokommunikációs eszközök robbanásszerü fejlődése; a társadalmi állapotok bizonytalanná válása a gyors változások következtében; a történeti kutatások valóságértékét relativizáló elméletek.

A korábban elnyomottak vagy háttérbe szorítottak felemelkedése, legyen szó akár a nőkről, a színes bőrü népességről, etnikai és vallási kisebbségekről, vagy a kommunista diktatúrák idején üldözött és elhallgattatott emberekről, szinte azonnal együtt járt a korábbi történelmi narratívák erős kritikájával. Az érintettek hamisnak, eltorzítottnak és rájuk nézve sértőnek kezdtek tekinteni szinte minden korábbi történelmi interpretációt, mivel ezek vagy egyáltalán nem jelenítették meg őket, vagy az elnyomásuk és háttérbe szorításuk indokaiként használt elöítéleteket erősítették meg ${ }^{3}$ Így aztán újabb és újabb társadalmi csoportok jelentették be az igényüket saját történelmük felkutatására és megírására. Az öntudatra ébresztés és a történelmi elégtétel célja folytán azonban ezen alternatív interpretációkban sem ritkák az egyoldalú megközelítések és a tények elfogult értelmezései, csak éppen a korábbiakkal ellentétes előjelekkel. Neil Ferguson szerint a mostani információrobbanás nagysága, dinamikája és történelmi jelentősége csak a reformáció korához, vagyis a könyvnyomtatás megjelenését követő változásokhoz mérhető. ${ }^{4}$ A népszerü angol történész abban is hasonlóságot lát a két korszak között, ahogy a közvetítő eszközök fejlődése és olcsóvá válása egyre szélesebb rétegek mozgósítását tette lehetővé, egyre élesebb vitákat gerjesztett, és egyre polarizáltabbá tette a közbeszédet. Figyelmeztető lehet, hogy a reformáció korában a szélsőséges hangvételü vitairatok, valamint a szándékosan terjesztett álhírek a feszültségek jóvátehetetlen elmérgesedéséhez és tömeges erőszakhoz vezettek az egymást kölcsönösen eretneknek bélyegző keresztény hívők között.

Az infotechnológia fejlődése más módon is hatással van a múlt feltárása körüli vitákra. A történelmi források és dokumentumok tömeges digitalizálása és elérhetővé tétele az interneten egyre nagyobb teret nyit a legkülönbözőbb nézeteket valló amatőr történelembúvárok számára is. Megszünőben van a hivatásos történészek elsődleges forrásokhoz jutásának monopóliuma, amely mindeddig az általuk készített múvek különleges tekintélyét és tudományos legitimációját biztosította. Nemcsak a források

2 Idézet egy Youtube-on talált hozzászólásból: „Magyar Tudományos Akadémia már régen lejáratta magát. Rengeteg bizonyíték van arra, hogy politikai célból terjesztik a téveszméket és rombolják a magyarok önbecsülését és kultúráját. Az MTA költségvetésének 70 százalékát a bérek és annak járulékai teszik ki. El lehet képzelni, hogy milyen tudományos munka zajlik ott a maradék 30\% pénzből. Jegyzőkönyv bizonyítja, hogy politikai döntés alapján nyomják ezt a finnugrista tévtant és még mindig vannak olyanok, akikben nincs szemernyi szégyenérzet sem, és a szájukra merik venni ezt a kultúrszemetet, ami egyenrangú történelemhamisítás a dáko-román handabandával... Aki erre képes az ne csináljon történelmi videókat, hanem menjen el kapálni..."

3 Friss példája volt ennek, amikor James Cook felfedező útjának 250. évfordulóján a maorik nem engedték kikötni a brit kapitány hajójának mását egy új-zélandi faluban. A helyi ngati kahu törzs vezetője Cookról azt mondta: „Semmit nem fedezett fel itt, ellenezzük a Tuia 250 rendezvénysorozatot, amely olyan eufemizmusokat használ, mint a 'találkozások' azért, hogy elleplezze a tulajdonképpeni inváziót." (Nagy-Britannia sajnálja, hogy a gyarmatositás során új-zélandi öslakosokat mészároltak le.

https://index.hu/kulfold/2019/10/02/nagy-britannia_sajnalja_hogy_a_gyarmatositas_soran_maori_torzseket meszaroltak le/)

4 Neil Ferguson: Networks and Power - The Long Now.

https://www.youtube.com/watch?v=hSacH_1BtVA 
elérése, hanem a múltról szóló interpretációk közönséghez való eljuttatásának lehetőségei is kiszélesedtek. A történelem iránt érdeklődő, laikus közvélemény a tartalmak passzív fogyasztójából a látottakra és olvasottakra nyilvánosan reflektáló, a saját személyes élményeit is megjeleníteni akaró aktív közönséggé vált, akár belterjes internetes közösségeket is létrehozva az azonos nézeteket vallók számára. Így még inkább felszívódnak a határok a mindennapi történelmi emlékezetben élő vélekedések, az ideológiai és propagandacélokat szolgáló történelmi fabrikációk és a történettudomány által megfogalmazott interpretációk és magyarázatok között.

A világ ma sokkal gyorsabban változik, mint bármikor korábban. Manapság egyetlen ember élete alatt is olyan mértékü változások zajlanak le, mint amilyenek hajdan csak több nemzedék alatt mentek végbe. A társadalmi állapotok folyamatos változásai, a korábbi közösségek és hagyományos értékrendek meggyengülése sokakat elbizonytalanít. Ez is a magyarázata lehet annak, hogy megnőtt az olyan valóságról alkotott, szimbólumokból, sok esetben történelmi szimbólumokból építkező ideológiák iránti igény, amelyek elutasítják a racionális vitákat és ellenállnak az igazságdiskurzusnak (Geertz, 1994). Akik úgy érzik, hogy rátaláltak egy számukra mindenre választ adó, így a múltban lejátszódottakat is megmagyarázó alapigazságra, egyszerüen figyelmen kívül hagyják, megkérdőjelezik, vagy éppen szenvedélyesen elutasítják az ezeknek ellentmondó tényeket és magyarázatokat.

Nagyon leegyszerüsített formában, de a közvélemény körében is ismertté váltak a 1980-as években elindult viták arról, hogy képes-e egyáltalán a történettudomány bármilyen érvényes megállapítást tenni a múltban lezajlott eseményekről (Fulbrook, 2002). Sokan azonosultak még a történészek és a történelemtanárok közül is azzal a posztmodernista felfogással, hogy a történelem vitákkal átitatott diskurzus, olyan csatatér, ahol a nemzetek, osztályok és csoportok megalkotják a múlt számukra kedvező interpretációit (Jenkins, 1991). Vagyis a történészek munkái is csak egy adott történelmi korszak gondolkodására jellemző interpretációk, amelyeket jelentős mértékben determinál a történész társadalmi-politikai környezete és személyes meggyőződése egyaránt. Ha pedig ez így van, a történettudományi viták nem dönthetők el azon az alapon, hogy melyik állítás áll közelebb a valósághoz. Megfogalmazódtak még olyan vélemények is, amelyek szerint semmi kifogásolni való sincs abban, ha két történelmi interpretáció közül a magunk politikai preferenciái alapján döntjük el, hogy 
melyiket tartjuk elfogadhatóbbnak. ${ }^{5}$ Nem csoda hát, hogy a laikus közvélemény körében is egyre többen kezdték el úgy kezelni, vagy akként beállítani a történészek által bemutatott következtetéseket és magyarázatokat is, mint amelyek szintén nem többek szubjektív véleményeknél.

Miért veszélyes, ha a történettudomány a maga kritikus, tényszerüségre és óvatosságra intő módján már nem képes megfelelő befolyást gyakorolni a társadalmi közgondolkodásra? Azért, mert enélkül maga a történelem válhat a valóságról alkotott kép szándékos vagy öntudatlan meghamisításának legfőbb tárgyává és eszközévé.

Az ember bal agyféltekéje folyamatosan olyan történeteket gyárt, amelyek által értelmet próbál adni mindannak, amit lát, hall és megtapasztal. A kutatások azt is bebizonyították, hogy e belső interpretáció gyártása, és ezáltal a valóságról szerzett tapasztalatok folyamatos átalakítása nem tudatos tevékenység. Az egyén nem képes ellenőrzése alatt tartani, mert nem is veszi észre, amikor önmagát ily módon manipulálja (Gazzaniga, 2011). Az egyén belső interpretációja a valóságról meghatározza, hogy mit gondol és tesz. Minél valósághübb és árnyaltabb ez az interpretáció, annál megfontoltabban gondolkodik és cselekszik. A belső interpretációk és az egyéni cselekedeteket meghatározó döntések ugyanakkor valószínüleg kölcsönhatásban állnak egymással. Hiszen a belső interpretáció célja éppen az, hogy a valóságról alkotott képet összhangba hozza azzal, amit az egyén tesz, vagy amit tenni szeretne. Ezért kialakulhat egy felfelé és egy lefelé vezető spirál egyaránt. Jó esetben a belső interpretáció értelmes döntésekhez vezet. Rossz esetben viszont a primitív belső interpretáció szélsőséges gondolatokra és cselekedetekre ösztönöz, ezek pedig megteremtik a belső szükségletét a világról alkotott kép további eltorzításának. „Az ember önmaga megvalósítója, szimbolikus modelleket konstruáló általános képességével létrehozza azokat a sajátos képességeket, amelyek meghatározzák. Vagyis [...] az ember ideológiák, a társadalmi rend sematikus képeinek konstruálásával válik jobb vagy rosszabb politikai állattá." (Geertz, 1994. 48.)

A múltról szóló interpretációk különösen erős hatást gyakorolnak az egyén belső interpretációira és ezáltal a gondolkodására és tetteire is. Nem csoda, hogy ezt a hatást mindig minden közösség ki akarja használni a maga egységének és cselekvőképességének megerösítésére. Nagy különbségek vannak azonban az ilyen célú interpretációk között a tekintetben, hogy milyen tettekre buzdítanak, milyen értékrendet állítanak fel, és milyen mértékben torzítják el a múltban történteket ${ }^{6}$. A mai modern társadalomban az egyén folyamatosan ki van téve egyoldalú történelmi igazságokat sulykoló manipulációknak, és az emberi természet eredendően inkább fogékony rájuk, mintsem hogy ellenállna ezeknek.

Ha féken akarjuk tartani a múlttal kapcsolatos tévedések, téveszmék és manipulációk terjedését, elsősorban a történettudományra támaszkodhatunk. Nem azért, mert a történészeket úgy általában tévedhetetlennek vagy „megvesztegethetetlennek” tarthatnánk, hanem mert ez a diszciplína rendelkezik azzal az intézményesített tudással, amelyre ehhez szükség van. A történészeknek a nemzetközi tudósközösség által kidolgozott és elfogadott kutatási módszereket és szabályokat alkalmazva kell dolgozniuk. A munkájuk

5 „A jelentős kérdés [nem az igazság, hanem] inkább a bizalom, amely sokféleképpen kialakulhat. Végül azonban a döntés, hogy bízom-e egy személyben, egy intézményben, egy forrásban vagy egy történelmi beszámolóban, számos tényező mérlegelésétől függ, és a végső ítélet a korábbi tapasztalatokon, politikai preferenciákon stb. alapul. Ezért a francia forradalom történetének egymással vitázó feldolgozásait nem lehet csak tisztán racionális kritériumok alapján értékelni.” (Jordanova, 2000. 96.)

6 „Míg az antidemokratikus nemzeti eszme által ihletett politikai szocializáció a nemzeti létet abszolutizálva a tekintélyelvet, a feltétlen engedelmességet és a nemzeti látószög egyedüli érvényét tekinti kívánatos nevelési célnak, addig a demokratikus nemzeti neveléskor a kölcsönös függőség és a felelősség elve, a világlátások lehetséges sokfélesége, a nyíltság és a türelem szempontja vezérli a szocializációs folyamatot." (Claussen, Wasmund, 1982). In. Csepeli György: Nemzet által homályosan. Századvég Kiadó, 1992. 90. 
eredményeit pedig szakmai diskurzusok keretében, szigorú minőségi kritériumoknak megfelelve kell bemutatniuk és megvédeniük. Nemcsak a történészek által feltártak megismerésére, hanem a rájuk jellemző kritikus szemlélet elsajátítására is szükségünk van ahhoz, hogy a mindennapi életben is kontrollálni tudjuk az elöítéletekre, történelmi önigazolásokra és leegyszerüsítő vélemények megfogalmazására való természetes hajlamunkat (Wineburg, 2007).

\section{Nyilvános történelem, történelmi emlékezet és a történettudomány}

A történelemtanítás is elsősorban a történettudományra támaszkodhat, amikor óvatosságra és kritikai beállítódásra igyekszik nevelni a fiatalokat. Megtanítani öket úgy is látni a világot, ahogy nem lennének képesek az iskolában megtanult szempontok és összefüggések nélkül. Ugyanakkor egy történelemtanár sokkal kevésbé függetlenítheti magát a nyilvános történelem és a történelmi emlékezet hatásaitól, és ami még fontosabb, nem tehet úgy, mintha a diákok történelemszemléletét csak az iskolában tanultak alakítanák.

A nemzetközi szakirodalomban sokszor találkozhatunk a heritage vagy a public history fogalmával. Ezen azt a tárgyi és szellemi „örökséget” értik, amelyet egy közösség a múltról nemzedékről nemzedékre áthagyományoz. Ebbe beletartozik minden, amit a jelen és a jövő szempontjából fontosnak tartanak megőrizni és továbbadni (pl. tárgyak, épületek, emlékmüvek, festmények, tradíciók, életrajzok, emlékiratok, történetek). Magyar nyelven a „történelmi hagyomány” vagy a „nyilvános történelem” fogalma feleltethetö meg a legjobban e jelentésnek. Ugyanakkor a heritage fogalmába ma már sokszor beleértik azt is, ahogy az emberek a mindennapi életben a maguk egyéni tapasztalatai, családi érintettségük vagy személyes benyomásaik szerint gondolkodnak a múlt egyes eseményeiről és szereplőiröl. Vagyis valami olyat is, amit mi ,történelmi emlékezetnek" hívunk inkább. Az angol nyelvü szakirodalomban is találkozni ma már a memory fogalmának ilyen értelmű használatával, megkülönböztetve azt a történész szakma által
A nemzetközi szakirodalomban sokszor találkozhatunk a heritage vagy a public history fogalmával. Ezen azt a tárgyi és szellemi „örökséget” értik, amelyet egy közösség a múltról nemzedékról nemzedékre áthagyományoz. Ebbe beletartozik minden, amit a jelen és a jövó szempontjából fontosnak tartanak megórizni és továbbadni (pl. tárgyak, épületek, emlékmúvek, festmények, tradiciók, életrajzok, emlékiratok, történetek). Magyar nyelven a „történelmi hagyomány” vagy a "nyilvános történelem" fogalma feleltethetó meg a legjobban e jelentésnek.

Ugyanakkor a heritage fogalmába ma már sokszor beleértik azt is, ahogy az emberek a mindennapi életben a maguk egyéni tapasztalatai, családi érintettségük vagy személyes benyomásaik szerint gondolkodnak a múlt egyes eseményeiról és szereplóiról. Vagyis valami olyat is, amit mi "történelmi emlékezetnek" híunk inkább. Az angol nyelvú szakirodalomban is találkozni ma már a memory fogalmának ilyen értelmú használatával, megkülönböztetve azt a történész szakma által múvelt történelemírástól. 
művelt történelemírástól. ${ }^{7}$ Leginkább e sokféle forrásból táplálkozó és sokféle rétegből álló közös történelmi emlékezet orientálja és motiválja a mindennapi emberek történelmi érdeklődését és identitását. Az ismeretforrások sokféleségéből, valamint a személyes tényezők és élmények komplexitásából következik, hogy akár egyes személyek, akár nagyobb közösségek történelmi emlékezetéről van szó, ezek nagyon stabil alapokon nyugszanak, és bár egyes részleteikben folyamatosan változnak, egészükban csak nagy történelmi megrázkódtatások hatására mennak át gyors és jelentős változásokon. A nyilvános történelem és a történelmi emlékezet együtt megfeleltethető annak, amit Jörg Rüsen „gyakorlati életnek” nevez, s amelynek lassú, de folyamatos változását egy önmagába visszatérő körkörös folyamatként ábrázolta (1. ábra).

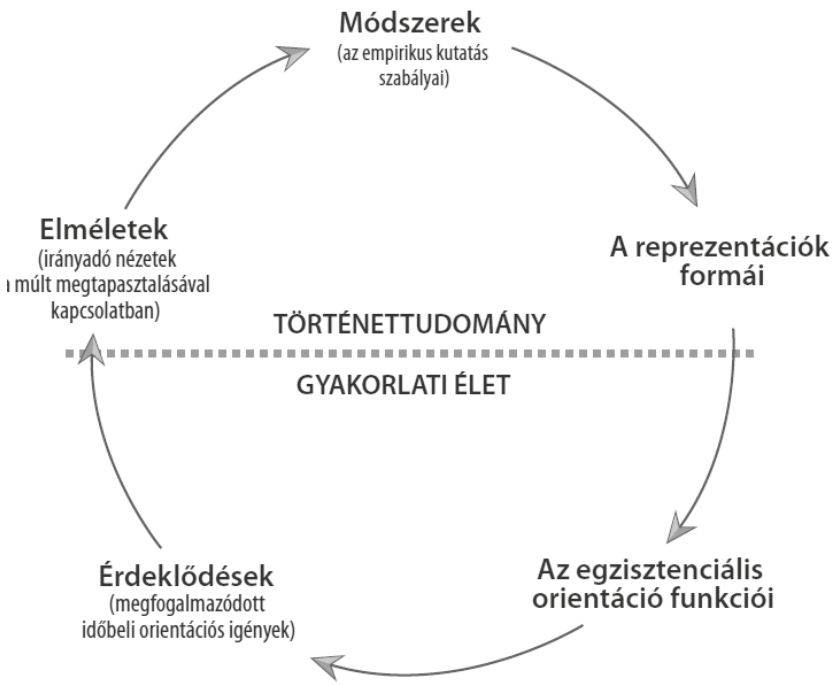

1. ábra. Jörg Rüsen modellje a mindennapi élet és a történettudomány kölcsönhatásáról (Megill, 1994. 49. alapján)

Rüsen abból indult ki, hogy az egyéneknek, közösségeknek, nemzeteknek mindig szükségük van időbeli orientációra. A Honnan jöttünk? és Hová tartunk? típusú kérdésekre való válaszkeresés természetes szükséglete az emberi gondolkodásnak. A közös történelmi emlékezet folyamatosan hatással van az emberek identitására, a jelenre és jövőre vonatkozó gondolkodására, életben tartva és alakítva az érdeklődésüket a múltban lejátszódott különböző események iránt. Az érdeklődés fókuszai folyamatosan változnak, más és más történelmi problémák és változások kerülnek előtérbe, megteremtve az igényt a múltban lejátszódottak pontosabb feltárásához. A mindenkori jelen aktuális problémái és változó érdeklődése különösképpen a mai modern, pluralisztikus társadalmakban állandóan új szempontokat és kérdéseket vetnek fel. Ezek pedig folyamatosan új impulzusokat adnak a professzionális történészeknek is, akik a közvéleményt foglalkoztató témákat kutatási kérdésekké alakítják át, és a maguk által kifejlesztett kutatási és bizonyítási módszerekkel igyekeznek válaszokat és magyarázatokat adni ezekre. Bár ők sem tudják

7 „,...a történelmi emlékezet [memory] mélyen átélt; megerősíti a közösség összetartozását, a kollektív identitásokat és a közös ellenségképeket; a múlt megőrzésével és kiszínezésével virágzik. A történelem [history] elemző és intellektuális; Pierre Nora kifejezését használva egyszerre »tartozik mindenkihez és senkihez«, és a bizonyítékokon alapuló kritikára és folyamatos felülvizsgálatra épül.” (Seixas, 2016) 
teljesen függetleníteni magukat a saját koruk társadalmi és kulturális környezetétől, az általuk készített interpretációk normális esetben túlmutatnak az ideológiák által vezérelt, vagy a mindennapi gondolkodásban élö ábrázolásokon. A történeti kutatások ethoszához ugyanis szorosan hozzátartozik egy kritikus és igazságkereső értékrend. A történetírás Rüsen megfogalmazásában ,túllép azon a partikularitáson, ahogy a mindennapi életben a »józan ész« orientálja a cselekedeteket” (Megill, 1994. 51.). A történészek kutatásainak új eredményei aztán különféle interpretációk formájában, sokféle csatornán keresztül ismertté válnak a szélesebb közvélemény körében is, gazdagítva és alakítva a közös történelmi emlékezetet (de Groot, 2009). Ez pedig együtt jár azzal is, hogy új szempontok és kérdések vetődnek fel, s a folyamat kezdődhet elölröl. E sokat hivatkozott modell magyarázatkísérlet arra, hogy az emberek múltról kialakított képe és a történettudományi kutatások miért vannak folyamatos változásban, és hogy e folyamatra miként gyakorol hatást a mindenkori jelen a maga problémáival és szemléletével. Rüsen mindezzel a múltról szóló interpretációk jelenre és jövőre gyakorolt hatásának jelentőségére is fel akarta hívni a figyelmet.

Napjaink történelmi vitái azt mutatják, hogy a mindennapi történelmi emlékezet és a történeti kutatások között lezajló párbeszéd és kölcsönhatás egyáltalán nem egyszerü és problémamentes. Egyre kétségesebb, hogy a történettudományi kutatások eredményei valóban beépülnek-e és hatással tudnak-e lenni a mindennapi gondolkodásra. F. Dárdai Ágnes már 2010-ben nálunk is elkezdte vizsgálni e probléma összetevőit (F. Dárdai, 2010). A történeti emlékezetet tápláló források (pl. képzőmüvészeti alkotások, állami megemlékezések, mondák, anekdoták, városi legendák, a történelmi témájú regények, filmek, számítógépes játékok) sokkal érdekesebbek és könnyebben elérhetők a fiatalok és a köznapi emberek számára is, mint a történettudományi források (pl. cikkek, tanulmányok, monográfiák, tudományos viták és konferenciák). Ráadásul a történeti hagyomány és emlékezet kész válaszokat kínál, amelyekkel könnyen lehet azonosulni (pl. hősök és gazemberek, barátok és ellenségek). Ezzel szemben a történettudományi szemléletre a termékeny bizonytalanság, a kétkedés és a kritikusság a jellemző, mert a történész nem fogadja el kritika nélkül a kész válaszokat. Folyamatosan új kérdéseket tesz fel, új források után kutat vagy újraértelmezi az azokból kiolvasható információkat, és ezeket használja fel a korábbi állítások megerősítésére vagy megcáfolására. Így aztán a történeti emlékezetben élő képhez képest sokkal ellentmondásosabb az, amit a történettudomány mond akár a nemzeti történelemről, akár az egyes eseményekről és szereplökröl (1. táblázat). Kérdés, hogy mennyire akar és tud a történelemtanítás közvetíteni a történelmi emlékezet és a történettudomány között.

1. táblázat. A történelmi hagyomány és a történettudomány által közvetitett kép a múltban történtekröl

\begin{tabular}{|c|c|}
\hline Történelmi hagyomány és emlékezet & Történettudomány \\
\hline $\begin{array}{l}\text { - nemzeti közösségtudat és büszkeség ápolása } \\
\text { - leegyszerüsített világ: hösök és gazemberek, } \\
\text { barátok és ellenségek, igazság és hamisság } \\
\text { - egyértelmü és kétségeket nem ismerö törté- } \\
\text { nelmi igazságtétel } \\
\text { - örök történelmi igazságok } \\
\text { - örök ellenségek } \\
\text { - erkölcsi igazolás és történelmi elégtétel } \\
\text { nyújtása }\end{array}$ & $\begin{array}{l}\text { - viták } \\
\text { - egymástól eltérő interpretációk } \\
\text { - bizonyítások és cáfolatok } \\
\text { - tárgyilagosság, önkritikus elemzések, érté- } \\
\text { kelések } \\
\text { - a múltra vonatkozó tudással kapcsolatos két- } \\
\text { ségek és bizonytalanságok elismerése, sőt } \\
\text { hangsúlyozása }\end{array}$ \\
\hline
\end{tabular}




\section{A történelemtanítás lehetséges szerepei}

A történelemtanítás általános céljainak meghatározásakor szinte mindig arról folyik a vita, hogy mi kapjon nagyobb hangsúlyt a történelemtanításban, a történelmi emlékezet pozitív megerösítésekre vágyó igénye, vagy a történettudomány tárgyilagos és kritikus szemlélete: „szeretni a hazát” vagy „megérteni a történelmet”. Egy 2018-ban lefolytatott kérdőíves kutatás keretében történelemtanároknak és középiskolai diákoknak a történelemtanítás 19 lehetséges feladatát kellett fontossági sorrendbe rakni (Jancsák, 2019). Az eredmény azt mutatja, hogy a tanárok és a diákok is mind a két célt egyaránt fontosnak tartják (2. táblázat), habár úgy tűnik, hogy a kritikai gondolkodás fogalmán nem ugyanazt értették.

2. táblázat. A magyar történelemtanárok és a tanulók vélekedése a történelemtanitás feladatairól (Jancsák, 2019. 19.)

\begin{tabular}{|l|c|c|}
\hline \multicolumn{2}{|c|}{ A történelemtanítás feladatai } & \multicolumn{2}{c|}{ RANGSOR átlagérték alapján } \\
\cline { 2 - 4 } & $\begin{array}{c}\text { történelem- } \\
\text { tanárok }\end{array}$ & tanulók \\
\hline Kollektív lokális és nemzeti emlékezet megôrzése & 1 & 2 \\
\hline Térben és idốben való tájékozódás fejlesztése & 2 & 1 \\
\hline Kritikai gondolkodás fejlesztése & 3 & 16 \\
\hline Nemzeti identitás megalapozása & 4 & 3 \\
\hline $\begin{array}{l}\text { A történelmi kulcsfogalmak helyes használatának } \\
\text { fejlesztése }\end{array}$ & 5 & 4 \\
\hline A történelmi fogalmi gondolkodás fejlesztése & 6 & 13 \\
\hline $\begin{array}{l}\text { Az ismeretek problémaközpontú } \\
\text { rendszerezéséhez szükséges kompetenciák } \\
\text { fejlesztése }\end{array}$ & 7 & \\
\hline
\end{tabular}

Peter Seixas a történelemtanítás alternatíváinak megvitatásához Rüsen modelljét fejlesztette tovább (2. ábra). Az iskolai történelemoktatást köztes sávként a mindennapi történelmi emlékezet és a történettudomány közé helyezte. A valóságban azonban a történelemtanítás célrendszere és gyakorlata általában elmozdul egyik vagy másik irányba. Az alsó mezőbe csúszás esetén a történelemtanítás a közgondolkodásban leginkább elterjedt és/vagy az aktuális hatalom részéről leginkább támogatott narratíva értelmezési keretét használja, és középpontjában az abban fontosnak tekintett történetek és hősök állnak. Az iskolai oktatás célja ilyenkor elsősorban ezek társadalmi köztudatba való bevitele és megerősítése anélkül, hogy eközben ,túl sok ablakot nyitna a kritikákhoz és a vitákhoz" (Seixas, 2016). Ezzel szemben a történelemtanítás felső mezőbe kerülésekor a föszerepet a történettudomány szemléletének és módszereinek elsajátítása kapja. Azzal a céllal, hogy ezek is segítsenek kialakítani azokat az elemző és értékelő képességeket, amelyekre egy pluralisztikus politikai rendszerben a fiataloknak szükségük van (Kölbl, 
2015; Lee, 2005). Ilyenkor még a nemzeti történelem forrásai és interpretációi is elsősorban a forráselemzés és a történeti ábrázolások kritikus olvasásának nyersanyagaiként jelennek meg.

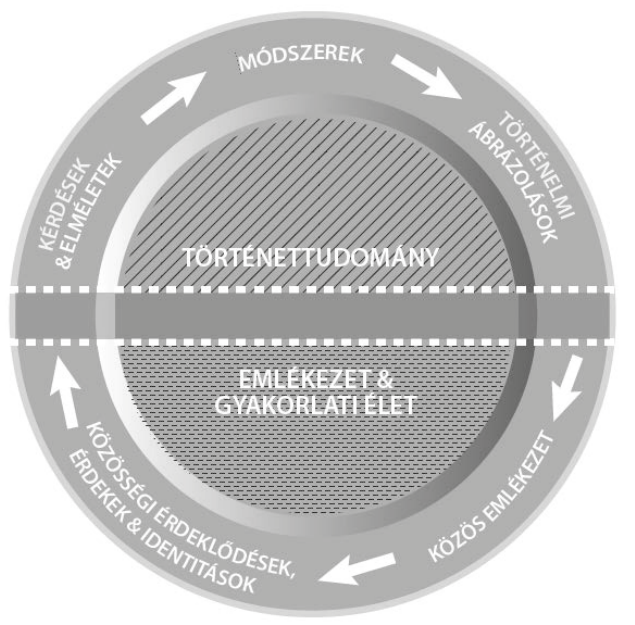

2. ábra. Peter Seixas (2016) modellje a történelemtanitás kontextusáról

A történelemtanítás e két jellemző vonulatát Mario Carretero „romantikus” és „felvilágosodott" hagyománynak nevezte (Carretero és Bermudez, 2012). Az utóbbi megjelenése a 70-es, 80-as években összefüggött a konstruktivista pedagógiai alapelvek elterjedésével. Haste szerint a kétféle felfogást az is jól megkülönbözteti egymástól, hogy az egyénben lejátszódó kognitív folyamatokat vagy a szociokulturális hatások szerepét tartják-e fontosnak (Haste, 1993). A konstruktivista modell az egyén mindennapi gondolkodását elbizonytalanító kihívásokat tartja a leghatékonyabb pedagógiai eszköznek a helyes történelmi gondolkodás kialakításához. Kognitív konfliktusokat alakít ki, vagyis konkrét példákon keresztül szembesíti a tanulókat a mindennapi történelmi gondolkodás hibáival és korlátaival, így alakítva ki bennük egy kritikus és reflektív beállítódást a múlt interpretációival kapcsolatban (Duquette, 2012). Mindeközben kisebb jelentőséget tulajdonít annak, hogy ez az új történelemszemlélet miként ágyazódik be a tanulót körülvevő szociokulturális folyamatokba és kontextusba. A konzervatív és a neokonzervatív megközelítések viszont éppen a tanulót körülvevő társadalmi kontextus szerepét emelik ki. Az egyén múltról alkotott felfogását alapvetően egy irányítható szocializációs folyamat termékének tartják. Tehát szerintük a kívánatos
Peter Seixas a történelemtanitás alternatíváinak megvitatásához Rüsen modelljét fejlesztette tovább (2. ábra). Az iskolai történelemoktatást köztes sávként a mindennapi történelmi emlékezet és a történettudomány közé helyezte. A valóságban azonban a történelemtanitás célrendszere és gyakorlata általában elmozdul egyik vagy másik irányba. Az alsó mezóbe csúszás esetén a történelemtanitás a közgondolkodásban leginkább elterjedt és/vagy az aktuális hatalom részéról leginkább támogatott narratíva értelmezési keretét használja, és középpontjában az abban fontosnak tekintett történetek és hôsök áll-

nak. Az iskolai oktatás célja ilyenkor elsốsorban ezek társadalmi köztudatba való bevitele és megerôsitése anélkül, hogy eközben "túl sok ablakot nyitna a kritikákhoz és a vitákhoz" (Seixas, 2016). Ezzel szemben a történelemtanitás felsố mezóbe kerülésekor a fốszerepet a történettudomány szemléletének és

módszereinek elsajátítása kapja. 
társadalmi céloknak megfelelő történelmi gondolkodást és tudást ki lehet alakítani a felnövekvő generációban anélkül is, hogy az egyes tanulókban ténylegesen lejátszódó mentális folyamatokkal különösebben foglalkozni kellene (Haste, 1993). Carretero szerint ez a magyarázata, hogy a konstruktivista kutatások miért nem szenteltek sok figyelmet az identitás ügyeinek, a történelemtanítás hagyományos romantikus szemléletü müvelői pedig miért nem foglalkoznak igazán az egyénekben lejátszódó aktív kognitív folyamatokkal. Carretero szerint ahhoz, hogy megérthessük a történeti narratívák teljes komplexitását, egy olyan szemléletű szintézisre lenne szükség a pedagógiai kutatásokban, amely megmagyarázandó problémaként kezeli azt is, ahogy az egyén a történelmi narratívákat befogadja, és azokat a kulturális folyamatokat is, amelyek során e narratívák létrejönnek és értelmezést nyernek. Valószínüleg ugyanilyen szintézisre lenne szükség a tanulók történelemszemléletének és történelmi tudatának eredményes alakításához is.

Seixas a híd szerepét tartaná kívánatosnak a történelemtanítás számára a köztudatban élö, nagyon sokféle forrásból táplálkozó mindennapi történelmi tudat és a történettudomány kritikus megközelítésmódja, illetve annak folyamatosan megújuló eredményei között. Szerinte ez a gyakorlatban azt jelenti, hogy képzett tanárok kellö szakmai autonómiával rendelkezve, lehetőségeket teremtenek a történelmi köztudatban élö és a diákok által is ismert vélemények kritikus történeti vizsgálatára. Vagyis az iskola a diákokon keresztül hatna vissza az egész közösség történelmi szemléletére és kultúrájára. Ez valójában nem egy köztes pozíció a közösségben élö történelmi emlékezet és a történettudományra jellemző kritikus szemlélet között. Alapvetően ez is a kritikus szemlélet kialakítását hangsúlyozza olyan módon, hogy az iskolában zajló kritikai elemzés még közvetlenebbül irányuljon a közösségi emlékezetben szerepet játszó eseményekre és történelmi ábrázolásokra.

Vannak, akik a történelemtanítás helyzetét Seixashoz képest sokkal determináltabbnak tartják. Például Sirkka Ahonen szerint a történelemoktatás nem az akadémiai történelem és a nyilvános történelem között helyezkedik el, hanem maga is a nyilvános történelem része (3. ábra). Nem az akadémiai történelem produktuma, mivel a tartalmát az állami emlékezetpolitika és az aktuális társadalmi igények határozzák meg. A történelemoktatók „összekapcsolják az episztemológiai érvényesség alapvető követelményeit a társadalmi relevancia és a pedagógiai megvalósíthatóság követelményeivel”' (Sirkka Ahonen, 2014). Ugyanakkor Ahonen szerint is a múltról szóló képet alakító három nagy terület kölcsönösen hat egymásra. Ennek a kölcsönhatásnak a feltárása nálunk is a történelemdidaktikai kutatások különösen fontos feladata lenne, például úgy, ahogy F. Dárdai Ágnes azt már régóta sürgeti: „Sokkal több empirikus kutatásra van szükség ahhoz, hogy megtudjuk, melyek a történelem tanulásának feltételei: milyen gondolkodási müveletek által jutnak el a tanulók a történeti fogalmakhoz, képzetekben? Hogyan formálódik történelmi identitásuk?" (F. Dárdai, 2006. 28.) 


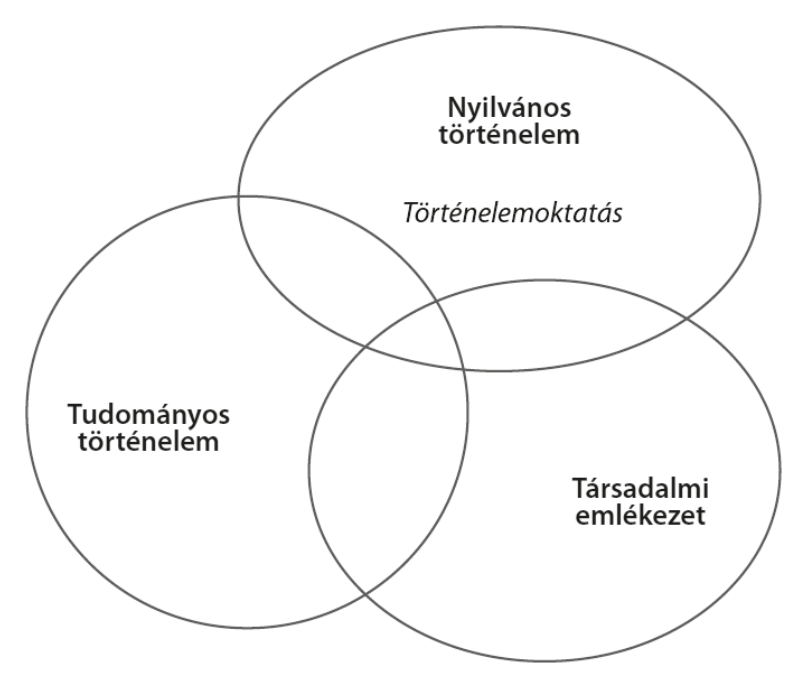

3. ábra. A történelem alkotásának területei (Ahonen, 2017. 44.)

Peter Lee is elfogadja a társadalmi igények relevanciáját az oktatásban, ugyanakkor a történelemtanítás autonómiáját még egy demokratikus társadalomban is fontosnak tartja megőrizni: ,a történelem nem arra szolgál, hogy bizonyos fajta állampolgárokat neveljünk ki [...] a történelemnek van néhány fontos közös értéke a demokráciával: feltételezi az érvelés szabadságát és a nyitottságot a tényeken alapuló érvekre. Feltételezi az emberek iránti tiszteletet, és azt, hogy egyenlöen kezeljük öket, mint az érvek forrásait. A történelemtanulás valószínüleg arra ösztönzi a tanulókat, hogy komolyan vegyék a demokráciát, de ez távolról sem jelenti azt, hogy az oktatásban az lenne a szerepe, hogy demokratákat neveljen.” (Bereta da Silva, 2012. 224.)

Nem könnyü és időnként zavarba ejtő szakmai feladat a történelemtanítás kétfajta céljának együttes megvalósítása. Egyszerre megadni a diákoknak a nemzeti hagyományokkal és történelmi közösséggel való azonosulás pozitív élményeit, ugyanakkor megtanítani őket az ezek alapjául szolgáló történelmi interpretációk és ábrázolások reflektív olvasására is. A fiatalabb tanulókkal könnyebben megszerettethető a történelemtanulás a lelkesítő és színes történetekkel, ezért ilyenkor érdemes megismertetni őket a közös történelmi hagyományt jelentő mondákkal, legendákkal, emlékhelyekkel, szimbólumokkal, a történelmi emlékezet által előtérbe állított hősökkel és hőstettekkel. Később aztán ugyanezen példákra vissza lehet térni a történelmi valóság és a történelmi emlékezet közötti ellentmondások vizsgálata céljából is. A történelmi emlékezettel és a történelmi interpretációkkal összefüggő reflektív gondolkodás kialakításának nagyon jó tárgya és terepe lehet a lakóhely múltjának kutatása is, összekapcsolva a helyi történéseket a nagy történelmi változásokról tanultakkal ${ }^{8}$. Számos nemzetközi példát találni már arra is, hogy a múlt egyes eseményeiről folyó aktuális viták, vagyis a történelmi emlékezet problematikája explicit módon is megjelenítik a történelemoktatásban. Konkrét példákon keresztül tudják ugyanis a leginkább megérteni a diákok, hogy miért válnak egyes

8 Kiváló példája ennek a Pécs8 program, emelynek célja a tudományos ismeretterjesztés olyan fórumainak megteremtése és összehangolása, melyek által a pécsi civilek is bekapcsolódhatnak Pécs 1945 és 1990 közötti története feltárásába.

https://pecs8.hu/ 
történelmi kérdések érzékeny társadalmi vitatémákká. Eközben megtapasztalják azt is, hogy a személyes élmények és a családi háttér is milyen meghatározó szerepet játszik abban, ahogy az emberek a múlt bizonyos eseményeihez viszonyulnak (van Boxtel és mtsai, 2015).

Az ilyen új megközelítésmódok és módszerek elterjedése azonban egy-egy országban nem a tanárok döntésén múlik elsősorban, hanem sokkal inkább az aktuális oktatáspolitika szándékaitól és a helyi társadalom általános történelmi kultúrájától függ.

\section{A történelmi tudat müködése és fejlődése}

A Seixas-féle modell segítségével felvázolt alternatívák akármelyike is csak akkor teljesülhet, ha a történelemórák képesek valódi hatást gyakorolni a diákok történelmi gondolkodására és tudatára. Éppen a megfelelő hatás elérése érdekében érdemes kihangsúlyozni, hogy itt két egymással összefüggő, de egymástól jól megkülönböztethető fejlesztési területről van szó. ${ }^{9}$ A történelmi gondolkodás alapvetően azzal foglalkozik, hogy a múlttal kapcsolatban milyen kérdésekre akarok választ találni, hol és hogyan keresek forrásokat és bizonyítékokat a lehetséges válaszokhoz, és mindezek alapján hogyan fogalmazom meg a válaszomat. E tekintetben a történettudomány vizsgálati módszerei és értelmezési keretei nyújtják a legjobb mintákat a történelmi témák iránt érdeklődőknek. Az iskola sokat tehet ezek megismertetéséért, sőt megvan a lehetősége arra is, hogy a történelemórákon végzett tevékenységekkel olyan képességet fejlesszen ki, olyan intellektuális eszközöket adjon a diákok számára, amelyek felnőttkorban és az élet más területein is jól alkalmazhatók lehetnek, pl. jó kérdések megfogalmazása,

9 E fogalmak értelmezése és definiálása áll annak a nemzetközi konferenciának a középpontjában is, amelyet a grazi egyetem rendez majd meg 2020 áprilisában (TÖRTÉNELMI TUDAT - TÖRTÉNELMI GONDOLKODÁS - TÖRTÉNELMI KULTÚRA

A történelemdidaktika és a történelemoktatás alapvetö fogalmai interkulturális perspektivákban. Reflexiók az eredményekre - Kihívások az új generáció számára.

https://grazconference2020.uni-graz.at/en/).
Nem könnyú és idónként zavarba ejtó szakmai feladat a történelemtanitás kétfajta céljának együttes megvalósítása. Egyszerre megadni a diákoknak a nemzeti hagyományokkal és történelmi közösséggel való azonosulás pozitív élményeit, ugyanakkor megtanitani óket az ezek alapjául szolgáló történelmi interpretációk és ábrázolások reflektív olvasására is. A fiatalabb tanulókkal könnyebben megszerettethetó a történelemtanulás a lelkesitó és szines történetekkel, ezért ilyenkor érdemes megismertetni óket a közös történelmi hagyományt jelentó mondákkal, legendákkal, emlékhelyekkel, szimbólumokkal, a történelmi emlékezet által elótérbe állitott hốsökkel és hóstettekkel. Késóbb aztán ugyanezen példákra vissza lehet térni a történelmi valóság és a történelmi emlékezet közötti ellentmondások vizsgálata céljából is. A történelmi emlékezettel és a történelmi interpretációkkal összefüggó reflektív gondolkodás kialakitásának nagyon jó tárgya és terepe lehet a lakóhely múltjának kutatása is, összekapcsolva a helyi történéseket a nagy történelmi változásokról tanultakkal. 
releváns információk összegyüjtése, különböző vélemények kritikus összehasonlítása, komplex helyzetértékelés, a saját vélemény tényekkel és érvekkel való alátámasztása (Kojanitz, 2013).

A történelmi tudat kérdései nem a múlt egyes eseményeire, hanem általában saját magam és a múlt közötti kapcsolatokról szólnak: pl. mekkora jelentőséget tulajdonítok a múltban történteknek; mi az, amit fontosnak tartok belőle megőrizni; miként formálják a múltról szerzett ismereteim az emberi világ müködéséről kialakított elképzeléseimet, miként befolyásolják a döntéseimet és azt, ahogy a jelenről és a jövőről gondolkodom. E személyes jelleg miatt a történelmi tudat kiformálódásában a családnak, a szociokulturális környezetnek és a személyes életútnak épp úgy szerepe van, mint a magam választotta életmintáknak, példaképeknek és eszmei ideáloknak. Ehhez a nagyon összetett személyiségterülethez kellene utat találni, amikor az egyes emberek történelmi tudatára és a társadalom általános történelmi kultúrájára szeretnénk hatást gyakorolni.

Stéphane Lévesque szerint a jelenről és jövőről alkotott kép és a múlt interpretációi közötti kölcsönhatás minősége annak a történelmi kultúrának a színvonalán múlik, amelyben mindez lejátszódik. A történelmi kultúra fogalma ebben az esetben magában foglalja mindazokat a diskurzusokat, amelyek arról szólnak, hogy a múltról konstruált elbeszélések tükrében egy közösség hogyan értelmezi önmagát és a jövőjét, és az egyének a saját jelenkori kultúrájuk tagjaiként miként reagálnak a múltban történtek emlékezetére (Lévesque, 2018). E tekintetben például nagyon eltérő megközelítésmódok jellemezhetik a múlttal intenzívebben foglalkozó egyéneket és csoportokat (pl. hagyományőrzők, emlékezetpolitikusok, lokálpatrióták, történelemtanárok, történészek) vagy a magasabb társadalmi elismerésért küzdő csoportokat (pl. nemzeti kisebbségek, vallási felekezetek, feministák).

Tipizálható-e az, ahogy az emberek a múltban történtekhez viszonyulnak, és ahogy a múlt, jelen és jövő kapcsolatáról gondolkodnak? Megragadhatók-e ebben minőségi különbségek, és ezekből felrajzolható-e egy potenciális fejlödési ív a történelmi tudat fejlesztéséhez? A legismertebb gondolatkísérletet erre vonatkozóan Jörg Rüsen tette meg, aki szerint a történelmi tudat által megvalósuló időbeli orientációnak van egy külső és egy belső nézőpontja. A történelem felfedi az emberi tevékenység által formált körülmények időbeli jellegét. Azt, hogy mindaz, ami körülvesz minket, és ami kívülröl determinálja a lehetőségeinket, egy időben folyamatosan lezajló változássorozat eredménye és pillanatnyi állapota. Ugyanakkor a történelem felfedi az emberi szubjektivitás, vagyis saját magunk megértésének időbeli dimenzióját is, vagyis azt, hogy amit magunkról gondolunk, ugyancsak időben formálódó identitásokból táplálkozik. Kialakul bennünk a történelmi identitás, és ezáltal egy nálunknál sokkal korábbtól létező és minket is túlélő „halhatatlan” közösség részének kezdjük érezni magunkat. A belsővé vált történelmi narratíva ,időbeli orientációt ad a gyakorlati élethez, mobilizálja az időbeliségről szerzett tapasztalatok emlékét, fejleszti az időbeli egészének zavarba ejtő fogalmát, és a gyakorlati élethez külső és belső időbeli perspektívákat ad" (Rüsen, 2006. 78.). Rüsen szerint a történelmi tudat mindezt három különbözö kompetencia, a tapasztalat konpetenciája (képes észrevenni és megragadni egy korszak jelentől eltérő sajátosságait), az értelmezés kompetenciája (képes a múlttal kapcsolatos tapasztalatait felhasználni a jelen és a jövőre vonatkozó várakozások megértéséhez) és az orientációs kompetencia (képes a múlt interpretációjának felhasználására a jelenlegi aktuális helyzet kezeléséhez) segítségével valósítja meg.

Azzal kapcsolatban, hogy ez az életben hogyan valósul meg, Rüsen négy jellemző típust különböztet meg: hagyományos, példakereső, kritikus és genetikus.

A hagyományos típusra a hagyományok életben tartása, a múlthoz való kötelmi kapcsolat érzése jellemző. Ez kifejeződhet a közös eredettudat fontosságának vagy a korábbi kulturális életminták, erkölcsi értékrendek folytonosságának hangsúlyozásában. Ebben a 
gondolkodásmódban a múlt a jelen és a jövő szempontjából szinte minden másnál fontosabb szerepet játszik.

A példakereső típus kulturális mintákat és az emberi életre jellemző szabályszerüségeket keres a múltban. Az események megismerésének jelentőségét számára az adja meg, hogy azok valamilyen jelennek szóló üzenetet és tanulságot hordozhatnak. Mindez azon a feltételezésen alapul, hogy az emberi magatartás jellemzői változatlanok, illetve a jelenben elfogadott értékrendek és erkölcsi elvek alkalmazhatók a múltra vonatkozóan is.

A kritikus típus az előző kettővel ellentétben tagadja a múltból fakadó és a múltban fellelhető örök kulturális és erkölcsi értékek létezését. Célja a történelem vizsgálatával éppen azt feltárni, hogy mindaz, amit a jelen követendő történelmi hagyományként ápol, politikai vagy kulturális szabályként követ, hogyan vezethető vissza egy korábbi korszak sajátos gondolkodásmódjára vagy aktuális érdek- és erőviszonyaira. A kritikus típus ellen-narratívákat készít, és ideológiai kritikát fogalmaz meg. A történelem ezáltal nemcsak elveszíti erejét és jelentőségét a jelenben és a jövőben, hanem sokkal inkább az elérni kívánt társadalmi és politikai viszonyok ellentéteként jelenítődik meg. Az 1888ban készült nemzetközi munkásinduló szövege jól példázza ezt a fajta szembeállítást: „A múltat végképp eltörölni, / Rabszolga-had, indulj velünk!”A genetikus vagy származtató típus történelemszemléletének középpontjában a változás áll, ez adja meg a múlt értelmét. A társadalmi élet teljes komplexitását az időbeli változás perspektívájából vizsgálja. Az identitás összetevőit is egy szüntelen változásból álló történelmi folyamattal összefüggésben vizsgálja. Az erkölcsi értékek fejlődését és változását a nézőpontok pluralizmusa szempontjából értelmezi. Vagyis a történelmet a jelen aktuális értelmezési keretében vizsgálja és értelmezi, lehetőséget adva, hogy az emberi tevékenység egy új világot hozzon létre. A régi kulturálisan öröklődött életmintákat pozitív „modern” konfigurációkká igyekszik átalakítani, a változtatásokkal téve lehetővé a megtartásukat. A jövőbeli lehetőségeket és korlátokat is a múltban történtekböl és a jelenben hozott döntésekböl igyekszik levezetni.

Rüsen szándéka e tipológia elkészítésével leginkább az volt, hogy segítséget adjon a történelemtanításnak a célok kijelöléséhez, illetve a tanulói megnyilvánulások értelmezéséhez a történelemi tudat fejlesztése szempontjából. Elképzelhetőnek tartotta azt is, hogy e tipológia valamilyen mértékben tükrözi a történelmi tudat érésének folyamatát is. A tanulók történelmi gondolkodásával foglalkozó empirikus kutatások ezt azonban nem látszanak alátámasztani.

$\mathrm{Az}$ is félrevezető lenne, ha azt gondolnánk, hogy az emberek mindig minden helyzetben ugyanolyan módon, csak az egyik, vagy csak a másik típusra jellemzően viszonyulnak a múltban történtekhez és azok interpretációihoz. Bizonyos történelmi eseményekkel kapcsolatban az egyén személyes érintettsége, egy közösség iránti magas fokú elkötelezettsége vagy vallásos hite jelentősen befolyásolhatja ezt. Vagyis lehet, hogy valakire alapvetően a kritikus vagy a genetikus történelemszemlélet a jellemző, de egyes témákhoz ö is inkább a tradicionális megközelítéssel és elkötelezettséggel viszonyul. ${ }^{10}$

${ }^{10}$ Egy néhány éve lezajlott kutatás keretében Sam Wineburg és munkatársa összehasonlította 8 vallásos történész és 8 szkeptikus történész szóbeli reflexióit olyan szövegek olvasása közben, amelyek témája pozitív szerepet játszik a vallásos emberek gondolkodásában (a bibliai Exodus és a Hálaadás története). Azt tapasztalták, hogy e történetek történeti valósággal való összevetése során a vallásosan elkötelezett történészek igyekeztek megoldást találni a vallásos meggyőződésük és a történettudóstól elvárt kritikus szemléletük közötti ellentmondásra. Wineburg ebből azt a következtetést vonta le, hogy még a hivatásos történészek esetében sem érdemes a történeti megértésről úgy gondolkodni, mint ami egy önmagával mindig megegyező egységes konstrukció. Szerinte ez inkább egy koordinátarendszerben mozog, amelynek vertikális tengelyét a történettudomány által meghatározott növekvő intellektuális kifinomultság, a horizontális tengelyét pedig az identitás és az elkötelezettség jelenti. A kísérlet egyik vallásos résztvevője ezt így fogalmazta meg: „az érettség azt jelenti, hogy megértjük a múlt értékét, ahogy azt a hagyomány ábrázolja, mert valójában az emberek 
Rüsen történelmi tudatról alkotott modelljei megtermékenyítően hatottak a történelemoktatás megújítását célzó elméleti és gyakorlati kutatásokra. Stéphane Lévesque (2018) szerint a történelmi tudat müködésében négy kompetencia játszik szerepet, és e kompetenciák müködését egy fogaskerekekböl álló modellel ábrázolta (4. ábra):

- Vizsgálati kompetencia: képesség történelmi kérdések kidolgozására és bizonyítékokon alapuló vizsgálatok elvégzésére.

- Történelmi gondolkodási kompetencia: képesség gondolkodni a témáról a történelmi kulcsfogalmak segítségéve (pl. történelmi jelentőség, történelmi változások, történelmi okok).

- Orientációs kompetencia: képesség összekapcsolni a múltra vonatkozó információkat és narratívákat a saját gyakorlati életével.

- Narratív kompetencia: képesség kiolvasni, létrehozni és megérteni a történeti narratívák szerkezetét. ${ }^{11}$

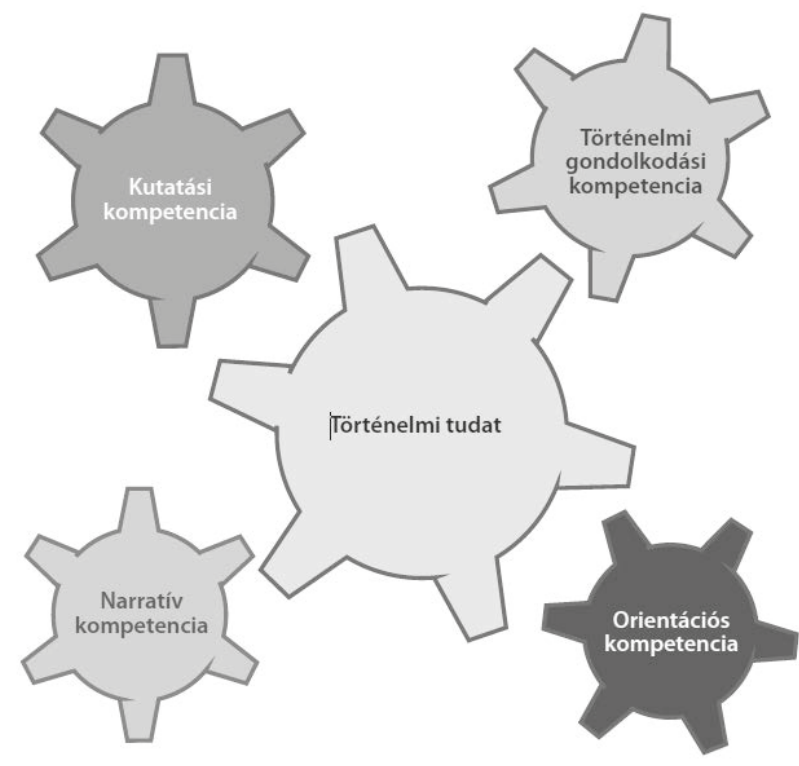

4. ábra. A történelmi tudatot mozgató kompetenciák (Lévesque, 2018)

Mindezt Lévesque a történelmi szimbólumok, például a történelmi személyeket ábrázoló szobrok körül felizzó vitákkal összefüggésben gondolta át. Úgy látta, hogy az egyes kompetenciák révén olyan kérdéseket tudunk megfogalmazni, amelyek segítenek az ilyen jellegü feszültségek higgadt megbeszélésében és feloldásában. Például az orientációs kompetencia ilyen jellegü kérdések mérlegelésére ösztönöz: Milyen tanulságokkal szolgál az adott történelmi személy tevékenysége és az utókor általi megítélésének változása? Hogyan befolyásolják az emlékmüvek a múltról és a jövőről alkotott képünket?

nem történészként élnek és halnak meg, hanem emberekként élnek és halnak meg... éltető táplálékra van szükségük a múltból; arra van szükségük, hogy körülöttük olyan emberek legyenek, akikkel közösek a gondolataik és az eszményeik, valamint az ethoszuk és az erkölcsi kereteik”. (Gottlieb és Wineburg, 2012. 102.)

11 Könnyen felismerhető ebben a Rüsen és a német történelemdidaktikusok által kialakított FUER modell hatása is, amelyben a történelmi gondolkodás kompetenciáján belül négy dimenziót különítettek el: vizsgálati kompetencia; módszertani kompetencia; a történelmi információk használata; szakismeret. Ez utóbbin elsősorban a történettudomány speciális fogalmainak alkalmazni tudását értve (Körber, 2011). 
Hogyan hat az ezekröl alkotott véleményemre az a szélesebb értelembe vett történelmi kultúra, amelyben élek?

Lévesque összekapcsolta a történelmi tudat általa meghatározott négy kompetenciáját: vizsgálati, gondolkodási, orinetációs, narratív, a történelmi gondolkodás Rüsen által leírt négy jellemző típusával: tradicionális, példakereső, kritikus, genetikus (3-6. táblázat). Ennek segítségével még árnyaltabban jellemezhetők a múlthoz való viszonyulások különböző típusai, és jobban elemezhetővé válik a történelemtanítás követelményrendszere, tartalma, módszertana, illetve az eredményessége a történelmi tudat kialakítása szempontjából.

3. táblázat. A kutatási kompetencia jellemzői a történelmi tudat különbözö típusaiban (saját forditás (Lévesque, 2018) (saját fordítás)

\begin{tabular}{|c|c|c|c|}
\hline Tradicionális & Példakereső & Kritikus & Genetikus \\
\hline $\begin{array}{l}\text { A múltban történ- } \\
\text { teknek csak egyetlen } \\
\text { helyes, a tekintélyek } \\
\text { által elismert rekonst- } \\
\text { rukciója van. } \\
\text { A múltra vonatkozó } \\
\text { kérdéseket úgy fogal- } \\
\text { mazzák meg, hogy } \\
\text { azokra egyszerú, } \\
\text { végleges válaszokat } \\
\text { lehessen adni a józan } \\
\text { ész és a mindennapi } \\
\text { élet tapasztalatai } \\
\text { alapján. }\end{array}$ & $\begin{array}{l}\text { A történet-tudomány- } \\
\text { nak megvan a maga } \\
\text { módszertana. } \\
\text { A kérdések arra szol- } \\
\text { gálnak, hogy összeha- } \\
\text { sonlítva a különbözö } \\
\text { korokban történteket, } \\
\text { a jelenre vonatkozóan } \\
\text { is hasznos tanulsá- } \\
\text { gokat vonhassunk le } \\
\text { belölük. }\end{array}$ & $\begin{array}{l}\text { A történet-tudomány- } \\
\text { nak megvan a maga } \\
\text { módszertana. } \\
\text { Különböző szem- } \\
\text { pontú kérdések } \\
\text { egymástól eltérő } \\
\text { kutatásokhoz és meg- } \\
\text { állapításokhoz vezet- } \\
\text { hetnek ugyanarról a } \\
\text { múltbéli eseményről } \\
\text { vagy korszakról. } \\
\text { Az egyének külön- } \\
\text { böző kérdéseket és } \\
\text { aggályokat vetnek fel, } \\
\text { felfedve a kulturális } \\
\text { relativitásokat. }\end{array}$ & $\begin{array}{l}\text { A történet-tudomány- } \\
\text { nak megvan a maga } \\
\text { módszertana. } \\
\text { A kérdéseket olyan } \\
\text { kontextusba helyezik, } \\
\text { és olyan vizsgálati } \\
\text { formákat és reprezen- } \\
\text { tációkat hoznak létre, } \\
\text { amelyek nyitottak a } \\
\text { kritikára és a felül- } \\
\text { vizsgálatra. } \\
\text { Tudatában vannak } \\
\text { annak, hogy a jövő } \\
\text { majd újabb kérdése- } \\
\text { ket fogalmaz meg a } \\
\text { múltra vonatkozóan. }\end{array}$ \\
\hline
\end{tabular}


4. táblázat. A történelmi gondolkodás jellemzői a történelmi tudat különbözö típusaiban

\begin{tabular}{|c|c|c|c|}
\hline & ô & & \\
\hline $\begin{array}{l}\text { A történelmi gondol- } \\
\text { kodási képességek } \\
\text { az előzetesen meg- } \\
\text { határozott erkölcsi } \\
\text { szabályok és minták } \\
\text { elfogadására korláto- } \\
\text { zódnak. } \\
\text { Nincs távolság a múlt } \\
\text { és a jelen között. } \\
\text { A hagyományok sta- } \\
\text { bilitást biztosítanak a } \\
\text { változás felett, ezért } \\
\text { nem kell megkérdő- } \\
\text { jelezni értéküket és } \\
\text { jelentőségüket. }\end{array}$ & $\begin{array}{l}\text { kodási képességek } \\
\text { egy jól bevált elemző } \\
\text { folyamat alkalmazá- } \\
\text { sát helyezik előtérbe, } \\
\text { amely örök érvényü } \\
\text { szabályok és a cselek- } \\
\text { vési alapelvek felis- } \\
\text { meréséhez vezethet. } \\
\text { A különböző ko- } \\
\text { rokban lezajlott } \\
\text { eseményekből és } \\
\text { változásokból szerzett } \\
\text { tapasztalatok értékes } \\
\text { tanulságokkal szol- } \\
\text { gálnak. }\end{array}$ & $\begin{array}{l}\text { A történelmi gondol- } \\
\text { kodási képességek } \\
\text { révén felismerjük a } \\
\text { magunk kontextuális } \\
\text { jellegét és meghatáro- } \\
\text { zottságát. } \\
\text { A történelmi jelentő- } \\
\text { ségről, az erkölcsről, } \\
\text { valamint a folytonos- } \\
\text { ságról és változásról } \\
\text { vallott felfogását } \\
\text { minden korszak a } \\
\text { maga értelmező kere- } \\
\text { te alapján alakítja ki. }\end{array}$ & $\begin{array}{l}\text { A történelmi gondol- } \\
\text { kodási képességek } \\
\text { fogalmakon, szabá- } \\
\text { lyokon és kritériumo- } \\
\text { kon alapulnak. } \\
\text { A kontextus a korok- } \\
\text { tól és helyszínekröl } \\
\text { függően változik, és } \\
\text { ez korlátozza annak } \\
\text { a lehetőségét, hogy a } \\
\text { múltbeli események- } \\
\text { ből általános követ- } \\
\text { keztetésekre jussunk } \\
\text { és saját erkölcsi fel- } \\
\text { fogásunkat a múltban } \\
\text { történtekre vetítsük. }\end{array}$ \\
\hline
\end{tabular}

5. táblázat. Az orientációs kompetencia jellemzői a történelmi tudat különbözö típusaiban (Lévesque, 2018)

\begin{tabular}{|c|c|c|c|}
\hline Tradicionális & Példakereső & Kritikus & Genetikus \\
\hline $\begin{array}{l}\text { A mindig is létezö } \\
\text { saját csoport élet- } \\
\text { felfogásának elfo- } \\
\text { gadása és követése. } \\
\text { A múlt, a jelen és a } \\
\text { jövö örökérvényü- } \\
\text { en összekapcso- } \\
\text { lódik. }\end{array}$ & $\begin{array}{l}\text { A konkrét elgon- } \\
\text { dolások és esetek } \\
\text { általános szabá- } \\
\text { lyokat és elveket } \\
\text { kínálnak a mai } \\
\text { életünkben történő } \\
\text { eligazodáshoz. } \\
\text { Az időbeliség di- } \\
\text { menzióit elismerik } \\
\text { és általános szabá- } \\
\text { lyokon keresztül } \\
\text { teremtenek kapcso- } \\
\text { latot közöttük an- } \\
\text { nak érdekében is, } \\
\text { hogy e szabályokat } \\
\text { a saját tevékenysé- } \\
\text { günk megtervezése } \\
\text { és értékelése során } \\
\text { is alkalmazni tud- } \\
\text { juk. }\end{array}$ & $\begin{array}{l}\text { Az egyének nem } \\
\text { éreznek semmilyen } \\
\text { kötelezettséget az } \\
\text { elödök iránt, ha- } \\
\text { nem megteremtik a } \\
\text { maguk értékrend- } \\
\text { jén alapuló cselek- } \\
\text { vési szabályokat. } \\
\text { A múlt, a jelen és a } \\
\text { jövő távol áll egy- } \\
\text { mástól, a kapcso- } \\
\text { latot közöttük csak } \\
\text { a szakítás élménye } \\
\text { jelenti. }\end{array}$ & $\begin{array}{l}\text { A folytonosság és a változás } \\
\text { összekapcsolódik, és ez alap- } \\
\text { vetö fontosságú a jelenben } \\
\text { történő eligazodás szempont- } \\
\text { jából is. Ez ad értelmet és } \\
\text { célt a történelemírásnak. } \\
\text { Az időbeliség vizsgálata } \\
\text { döntő eszköze a történelmi } \\
\text { követelések és az erkölcsi } \\
\text { értékek érvényességéről } \\
\text { való döntésnek. A korszakok } \\
\text { összekapcsolódnak a jövő- } \\
\text { beli lehetőségekhez vezető } \\
\text { útként. } \\
\text { A korszak sajátosságainak } \\
\text { figyelembe vétele fontos } \\
\text { feltétele a történelmi állítások } \\
\text { és erkölcsi értékek érvényes- } \\
\text { ségének. } \\
\text { A különböző dimenziói a } \\
\text { jövő lehetőségeihez vezető } \\
\text { útként kapcsolódnak össze. }\end{array}$ \\
\hline
\end{tabular}



(Lévesque, 2018)

\begin{tabular}{|c|c|c|c|}
\hline Tradicionális & Példakereső & Kritikus & Genetikus \\
\hline $\begin{array}{l}\text { A történelmi elbeszé- } \\
\text { lések közvetlen abla- } \\
\text { kot nyitnak a múltra, } \\
\text { igaz történeteket } \\
\text { mondanak el, ame- } \\
\text { lyek megerösítik a } \\
\text { jelenkor embereinek } \\
\text { kapcsolatát a múlttal, } \\
\text { és megszilárdítják az } \\
\text { identitásukat. }\end{array}$ & $\begin{array}{l}\text { A narratívák olyan } \\
\text { történeti ábrázolások, } \\
\text { amelyek hasznos ta- } \\
\text { nulságokat nyújtanak } \\
\text { történeti általánosítá- } \\
\text { sokkal vagy referen- } \\
\text { ciapontokkal. }\end{array}$ & $\begin{array}{l}\text { A narratívák ellenér- } \\
\text { veket fogalmaznak } \\
\text { meg a korábban } \\
\text { érvényesnek tekintett } \\
\text { narratívával szemben, } \\
\text { és segítenek megfo- } \\
\text { galmazni egy másik } \\
\text { megalapozott narratív } \\
\text { álláspontot. }\end{array}$ & $\begin{array}{l}\text { A narratívák a múlt } \\
\text { valósághű reprezen- } \\
\text { tációit kínálják az } \\
\text { életünk irányításához, } \\
\text { amelyek azonban nyi- } \\
\text { tottak a felülvizsgá- } \\
\text { latra és ellenőrzésre. } \\
\text { A különböző állás- } \\
\text { pontok az elfogad- } \\
\text { hatóságuk mértéke } \\
\text { alapján értékelhetők, } \\
\text { és összhangba hozha- } \\
\text { tók egy változásokon } \\
\text { alapuló jövőképpel. }\end{array}$ \\
\hline
\end{tabular}

A Lévesque készítette mátrix legnagyobb erénye, hogy a tanítás és a tanulás szempontjából is jól megragadhatóvá teszi a történelmi gondolkodás és a történelmi tudat közötti összefüggéseket és kölcsönhatásokat. Ugyanakkor valószínűleg tévedés lenne a mátrixot úgy értelmezni, hogy a tanulók fejlődése egy olyan lineáris folyamat, amely a tradicionálistól a genetikus történelmi tudat felé tart. Andreas Körber szerint a történelmi tudat fejlödési szintjei közötti különbség inkább azzal jellemezhető, hogy valaki mennyire van tudatában e különböző megközelítésmódoknak, mennyire képes mások és a saját megnyilatkozásaiban észrevenni, hogy mikor melyik szerint alakít ki valaki véleményt a múltban történtekröl. Ez a tudatosság szükséges ugyanis ahhoz, hogy differenciáltan tudjuk értelmezni a magunk és mások megközelítésmódját a különböző történelmi eseményekhez, és képesek legyünk észrevenni, milyen szerepet játszanak e megközelítésmódbeli eltérések a történelmi vitákban.

„Alap” szinten még nincs meg a képesség a történelmi elbeszélés különféle módjainak a megkülönböztetésére. Vagyis a korai szakaszra nem a „hagyományos” történelmi tudat, hanem a mintázatok nem tudatos (vagy esetleg csak félig megértett) keveredése a jellemző. Egy következő szintet jelent, amikor valaki a különféle mintázatokat már képes különböztetni, és felismeri inkonzisztens összekeveredésüket. Képes felismerni, ha a történelmi viták hátterében általános történelemszemléleti különbségek húzódnak meg. Például amikor egy múltbeli esemény pozitív megítélését az egyik vitázó fél egy számára fontos történelmi hagyomány lényeges elemeként, míg a másik fél ugyanezt a koronként változó történelmi interpretációk egyszerü példájaként kezeli. A differenciált látásmód 
jelentős segítséget adhat az egymással szemben álló vélemények mélyebb megértéséhez és kritikus mérlegeléséhez. Ez feltétele lehet egy olyan belső fejödésnek is, amelynek során valaki képes felismerni a maga tradicionális vagy példakereső beállítottságát és annak korlátait. Mint ahogy Körber (2018) szerint a legmagasabb szintet az jelent, amikor képes valaki reflektíven látni e tipológia értékét és korlátait is.

\section{A történelemtanításra vonatkozó célok elemzése a történelmi tudat kialakítása szempontjából}

Az iskolai történelemtanítás számára elöírt tantervek mindegyike fontos feladatként kezeli a diákok történelmi tudatának fejlesztését. Az aktuális társadalmi és oktatáspolitikai igényektől függően viszont eltérnek a tekintetben, hogy elsősorban milyen természetű történelmi tudatot kívánnak kialakítani és megerősíteni. Az erre vonatkozó dokumentumok összehasonlításához és a közöttük megfigyelhető különbségek értelmezéséhez is hasznos szempontrendszer lehet a Stéphane Lévesque által készített mátrix. Ennek segítségével pontosabban megkülönböztethetjük egymástól még ugyanazon szövegeken belül is a tradicionális, a példakereső, a kritikus vagy a genetikus megközelítésű célkitűzéseket. A módszer kipróbálásaként elemeztem az új NAT 2018-ban bemutatott első tervezetének szövegét (A Nemzeti alaptanterv tervezete, 2018. augusztus 31.). A tartalomelemzés szövegkorpusza a Történelmi és állampolgári ismeretek rész szöveges bevezetőjének történelemtanításra vonatkozó részei voltak: alcím nélküli általános bevezető, Általános alapelvek, Célkitűzések, Kapcsolódás a kompetenciákhoz. E szövegekben jellemző példákat találtam mind a négy kompetenciaterülethez és mind a négyfajta történelmi tudathoz kapcsolható célkitűzésekre (7-10. táblázat).

7. táblázat. Példák a kutatási kompetenciára vonatkozó célkitüzésekre a NAT 2018-ban a Rüsen-féle tipológia szerint szétválogatva

\begin{tabular}{|c|c|c|c|}
\hline Tradicionális & Példakereső & Kritikus & Genetikus \\
\hline & $\begin{array}{l}\text { Az életmódtörténeti } \\
\text { modulok feldolgo- } \\
\text { zása révén a tanuló a } \\
\text { különbözö történelmi } \\
\text { korok termelőte- } \\
\text { vékenységében és } \\
\text { munkakultúrájában } \\
\text { elkülöníti az általános } \\
\text { emberi vonásokat, } \\
\text { illetve a korszakra } \\
\text { jellemző specifiku- } \\
\text { mokat. }\end{array}$ & & $\begin{array}{l}\text { A történelem termé- } \\
\text { szete szerint értelme- } \\
\text { zö jellegü, a tényekröl } \\
\text { alkotott különböző } \\
\text { vélemények szükség- } \\
\text { szerüen vitákat ered- } \\
\text { ményeznek. A viták } \\
\text { úgy szolgálhatják a } \\
\text { történelemtanulást, ha } \\
\text { nyomukban a tanu- } \\
\text { lókban világossá válik } \\
\text { a történelmi tény és } \\
\text { interpretáció közötti } \\
\text { különbség, illetve } \\
\text { ha megerősödnek } \\
\text { bennük társadalmunk } \\
\text { és civilizációnk alap- } \\
\text { értékei. }\end{array}$ \\
\hline
\end{tabular}


8. táblázat. Példák a történelmi gondolkodásra vonatkozó célkitüzésekre a NAT 2018-ban a Rüsen-féle tipológia szerint szétválogatva

\begin{tabular}{|c|c|c|c|}
\hline Tradicionális & Példakereső & Kritikus & Genetikus \\
\hline $\begin{array}{l}\text { A történelmi ismere- } \\
\text { tek részei annak az } \\
\text { európai és magyar } \\
\text { kulturális kódrend- } \\
\text { szernek, amely ci- } \\
\text { vilizációnk szellemi } \\
\text { fundamentumát jelen- } \\
\text { ti, és ezáltal lehetóvé } \\
\text { teszik, hogy a tanulók } \\
\text { azonosulni tudjanak } \\
\text { kultúránk alapértéke- } \\
\text { ivel, illetve képesek } \\
\text { legyenek társadalmi } \\
\text { és kulturális téren a } \\
\text { hatékony és árnyalt } \\
\text { kommunikációra. }\end{array}$ & & $\begin{array}{l}\text { A különböző korok és } \\
\text { kultúrák életmódjának, } \\
\text { világképének, értékeinek } \\
\text { megismerése hozzájárul a } \\
\text { toleráns és elöítéletmentes } \\
\text { gondolkodás kialakításá- } \\
\text { hoz. A tanuló kritikusan } \\
\text { szemléli az elöítéletes } \\
\text { gondolkodást, arra tö- } \\
\text { rekszik, hogy az emberi } \\
\text { cselekedeteket, életutakat, } \\
\text { élethelyzeteket, társadalmi } \\
\text { folyamatokat és jelensége- } \\
\text { ket árnyaltan értelmezze. } \\
\text { A társadalmakra, közössé- } \\
\text { gekre jellemző magatartási } \\
\text { és kommunikációs szabá- } \\
\text { lyok felismerése a tanuló } \\
\text { alkalmazkodóképességét, } \\
\text { adaptációs attitüdjét fej- } \\
\text { leszti. Tiszteli a másik } \\
\text { embert, ugyanakkor a } \\
\text { különböző életutakhoz ér- } \\
\text { telmezően viszonyul, ezzel } \\
\text { önismerete, önbecsülése is } \\
\text { erösödik. }\end{array}$ & $\begin{array}{l}\text { A tanuló a történelem- } \\
\text { tanulás során külön- } \\
\text { féle jellegü tudástar- } \\
\text { talmakkal (például } \\
\text { lexikai jellegú mú- } \\
\text { veltségi elemekkel, } \\
\text { illetve oksági össze- } \\
\text { függésekkel, struktú- } \\
\text { rákkal) és különbözö } \\
\text { típusú feladatokkal } \\
\text { találkozik, amelyek } \\
\text { megtanulásához, } \\
\text { illetve elvégzéséhez } \\
\text { különféle stratégiá- } \\
\text { kat kell választania. } \\
\text { A történelmi infor- } \\
\text { mációk keresése és } \\
\text { feldolgozása, a for- } \\
\text { ráskritika, a következ- } \\
\text { tetések levonása és } \\
\text { egyéb gondolkodási } \\
\text { múveletek transzfer } \\
\text { hatásuk révén általá- } \\
\text { ban fejlesztik a tanu- } \\
\text { lási kompetenciákat. }\end{array}$ \\
\hline
\end{tabular}

9. táblázat. Példák az orientációs kompetenciára vonatkozó célkitüzésekre a NAT 2018-ban a Rüsen-féle tipológia szerint szétválogatva

\begin{tabular}{|c|c|c|c|}
\hline Tradicionális & Példakereső & Kritikus & Genetikus \\
\hline $\begin{array}{l}\text { A magyar történe- } \\
\text { lem eseményeiről és } \\
\text { szereplöirőll kiala- } \\
\text { kított reális kép, a } \\
\text { büszkeségre okot adó } \\
\text { történelmi cselekede- } \\
\text { tek, eredmények és } \\
\text { emberi teljesítmények } \\
\text { megismerése el- } \\
\text { mélyíti a hazaszeretet } \\
\text { érzését. }\end{array}$ & $\begin{array}{l}\text { A tanuló a különbö- } \\
\text { ző történelmi korok } \\
\text { mindennapi életének } \\
\text { vizsgálatával, az } \\
\text { életmód változatos } \\
\text { formáinak, valamint } \\
\text { történelmi életutaknak } \\
\text { és cselekedeteknek } \\
\text { a megismerésével } \\
\text { viszonyítási pontokat } \\
\text { találhat, illetve kö- } \\
\text { vethető modelleket } \\
\text { adaptálhat saját élet- } \\
\text { útjának tervezéséhez } \\
\text { és szervezéséhez. }\end{array}$ & & $\begin{array}{l}\text { A tanulók a törté- } \\
\text { nelemtanulás során } \\
\text { megtapasztalják, hogy } \\
\text { a történelemtudásuk } \\
\text { az iskolán kívül, más } \\
\text { élethelyzetekben, illetve a } \\
\text { jelen társadalmi, gazdasági } \\
\text { és politikai jelenségeinek } \\
\text { megértéséhez és meg- } \\
\text { ítéléséhez is segítséget } \\
\text { nyújt. Ez a tapasztalat - az } \\
\text { iskolai történelemtanulás } \\
\text { élményszerüsége mellett } \\
\text { - erős inspirációt adhat az } \\
\text { élethosszig tartó tanulásra } \\
\text { vagy legalábbis a történel- } \\
\text { mi és társadalmi kérdések } \\
\text { iránti érdeklődésre. }\end{array}$ \\
\hline
\end{tabular}


10. táblázat. Példák a narratív kompetenciára vonatkozó célkitüzésekre a NAT 2018-ban a Rüsen-féle tipológia szerint szétválogatva

\begin{tabular}{|c|c|c|c|}
\hline Tradicionális & Példakereső & Kritikus & Genetikus \\
\hline $\begin{array}{l}\text { Büszke a magyar } \\
\text { tudósok, müvészek, } \\
\text { sportolók és más } \\
\text { értékteremtő, alkotó } \\
\text { emberek kiemelkedő } \\
\text { eredményeire, teljesít- } \\
\text { ményeire. }\end{array}$ & $\begin{array}{l}\text { A technikai találmá- } \\
\text { nyok és tudományos } \\
\text { felfedezések kapcsán } \\
\text { kiemeli az egész } \\
\text { emberiséget szolgáló } \\
\text { pozitív vonatkozáso- } \\
\text { kat, egyúttal kritiku- } \\
\text { san értékeli a negatív } \\
\text { hatásokat, mérlegeli } \\
\text { a következmények } \\
\text { súlyát is. }\end{array}$ & & $\begin{array}{l}\text { A történelem az em- } \\
\text { beri közösségeknek } \\
\text { a múltról alkotott } \\
\text { tudása; egyfelől az } \\
\text { emberekkel megtör- } \\
\text { tént eseményekről } \\
\text { tanúskodó különböző } \\
\text { források és bizonyí- } \\
\text { tékok, másfelől az } \\
\text { ezekről alkotott inter- } \\
\text { pretációk és vélekedé- } \\
\text { sek összessége. }\end{array}$ \\
\hline
\end{tabular}

A NAT 2018 is azt példázza, hogy a régi és az új követelményrendszerek valószínűleg nem abban különböznek egymástól, hogy kizárólag egyik vagy másik típusú történelmi tudatra jellemző célokat jelölnek ki. A különbséget sokkal inkább e célkitűzések arányaiban kifejeződő hangsúlyok jelenthetik. A NAT 2018 esetében jól érzékelhetően a genetikus történelmi tudatra jellemző általános célkitűzések kerültek előtérbe (5. ábra).

NAT 2018 Történelmi és állampolgári ismeretek - Általános alapelvek

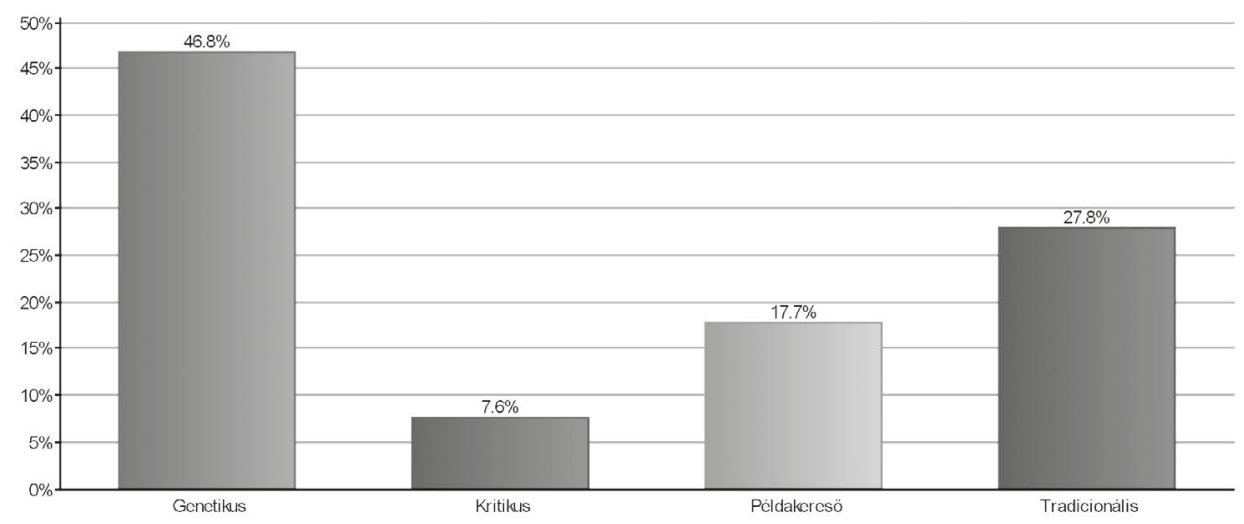

5. ábra. A különbözö típusú történelmi tudatra jellemzö általános célkitüzések aránya a NAT 2018-ban

Kérdés persze, hogy a részletes követelményekben, az ezek alapján készülő taneszközökben és majd a tanári gyakorlatban megmaradnak-e ugyanezek a hangsúlyok, és érvényesül-e például, hogy „A tanulók a történelemtanulás során megtapasztalják, hogy a történelemtudásuk az iskolán kívül, más élethelyzetekben, illetve a jelen társadalmi, gazdasági és politikai jelenségeinek megértéséhez és megítéléséhez is segítséget nyújt.". Az is elképzelhető, hogy a NAT 2018 jelenleg zajló átdolgozása a tradicionálisnak nevezhető történelmi tudat pozícióit erösíti meg a véglegesen elfogadott új Nemzeti alaptantervben. Mindenesetre érdemes lesz majd ilyen szempontból is összehasonlítani a Történelmi és állampolgári ismeretek rész eredeti és átdolgozott szövegét. 


\section{Összegzés}

A történelemoktatás válságban van, és ez a válság összefügg az általános történelmi kultúra leépülésével. Miközben jó esetben a történelemtanítás igyekszik továbbra is a történettudomány szemléletét és a történeti kutatások eredményeit közvetíteni, a mindennapi életben és a médiákban zajló viták tartalma és hangneme, az emberek történelmi múltról alkotott képe egyre jobban távolodik ettől. Az tapasztalható, hogy a történettudomány csak korlátozottan tud befolyást gyakorolni a közgondolkodásra, és sokszor maga a történelem válik a valóság meghamisításának tárgyává és eszközévé. A diákok is rendszeresen találkoznak egyoldalú és szélsőséges véleményekkel, és sokszor látják azt is, hogy a politikai szekértáborok már csak a maguk által megkonstruált történelmi narratívát hajlandók egyedül érvényesnek tekinteni. Mindezen körülmények folyamatosan negatív hatással vannak az ö történelemszemléletükre is. Ilyen helyzetben kellene a történelemoktatásnak újra megtalálni a maga helyét és szerepét. Képes lehet-e a történelemtanítás mindezt ellensúlyozni? Mire lenne szükség ahhoz, hogy az iskolai történelemoktatás az általános történelmi kultúrára is kedvező hatással tudjon lenni?

A problémák nem szűkíthetők le egy országra vagy egy régióra, különböző mértékben, de a kedvezötlen tendenciák világszerte megtapasztalhatók. Ezért mindez a nemzetközi történelemdidaktikai kutatásokban is egyre nagyobb figyelmet kap. Elötérbe került a történettudomány, a történelmi emlékezet, a nyilvános történelem, a hivatalos emlékezetpolitika és a történelemoktatás közötti kölcsönhatások vizsgálata. Egyrészt abból a szempontból, hogy az új célok kijelölése milyen szakmai, társadalmi és politikai erőtérben kellene, hogy megtörténjen, másrészt úgy is, hogy ezek a kölcsönhatások milyen módon hatnak a diákokra. Ezzel összefüggésben a történelmi gondolkodás mellett egyre nagyobb hangsúlyt kap a diákok történelmi tudatának kutatása és fejlesztése is. Különös tekintettel arra, hogy a történelemszemlélet alakulása miként ágyazódik be a tanulót körülvevő szociokulturális folyamatokba, illetve hogy a történelmi gondolkodás és a történelmi tudat fejlődése közötti összefüggések miként ragadhatók meg a tanítás és a tanulás szempontjából. A nemzetközi kutatások eredményeinek folyamatos nyomon követése nekünk is segíthet megérteni a történelemoktatás céljairól folyó viták jelentőségét, valamint az általuk kidolgozott elméleti keretek és értékelési szempontok felhasználásával mi is megalapozottabban kezdhetünk hozzá a jelenlegi gyakorlat átalakítását szolgáló történelemdidaktikai kutatásokhoz és fejlesztésekhez.

\section{Irodalom}

A Nemzeti alaptanterv tervezete, 2018. augusztus 31.

https://www.oktatas2030.hu/wp-content/uploads/ 2018/08/a-nemzeti-alaptanterv-tervezete 2018.08.31. pdf

Ahonen, S. (2017). The Lure of Grand Narratives: A dilemma for history teachers. In Åström Elmersjö, H., Clark, A. \& Vinterek, M. (szerk.), Basingstoke: Palgrave Macmillan. 41-62. DOI: 10.1057/978-1-13755432-1 3

Bereta da Silva, C. (2012). History Education - some thoughts from The UK: interviews Peter J. Lee. Tempo e Argumento Florianópolis, 3(2), jul/dez.
Carretero, M. \& Bermudez, A. (2012). Constructing histories. In Valsiner, J. (szerk.), Oxford library of psychology. The Oxford Handbook of Culture and Psychology. New York, NY, US: Oxford University Press. 625-645.

de Groot, J (2009). Consuming History Historians and heritage in contemporary popular culture. Routledge. DOI: 10.4324/978020388900

F. Dárdai Ágnes (2010). Történelemtanítás Magyarországon a XXI. század elején. Történelemtanitás, 2.

http://www.folyoirat.tortenelemtanitas.hu/2010/02/ fischerne-dardai-agnes-tortenelemtanitas-magyarorszagon-a-xxi-szazad-elejen-helyzetkep-es-perspektiva/ 
F. Dárdai Ágnes (2006). A történelemtanulás sajátosságai. In Történelmi megismerés - Történelmi gondolkodás I. ELTE BTK; MTT Tanári tagozata.

Duquette, C. (2012). The Connection Between Historical Thinking and Historical Consciousness: Proposition of a New Taxonomy. Paper presented at the Assessment of Historical Thinking Conference, Toronto, ON.

Fulbrook, M (2002). Historical Theory. London: Routledge. DOI: 10.4324/978020345065

Gazzaniga, M. S. (2011). Who's in Charge? Free Will and the Science of the Brain. New York: Ecco.

Geertz, C.(1994). Az ideológia mint kulturális rendszer. In uő, Az értelmezés hatalma. Budapest: Századvég Kiadó. 22-62.

Gottlieb, E. \& Wineburg, S. (2012). Between Veritas and Communitas: Epistemic Switching in the Reading of Academic and Sacred History. Journal of the Learning Sciences, 21(1), 84-129. DOI: 10.1080/10508406.2011.582376

Haste, H. (1993). Morality, Self an d Sociohistorical Context: The Role of Lay Social Theory. In Noam, \& Wren, T. (szerk.), The Moral Self. Cambridge, MA: The MIT Press. 175-208.

Hermann Róbert (2019). „Kossuth politikai manipulációja”. Hermann Róbert hadtörténész Görgei Artúr zsenijéröl. Magyar Narancs, 10. https://magyarnarancs.hu/tudomany/konnyu -volt-raverni-a-felelosseget-117841?fbclid=IwAR2 to361YJsuzcrIAJxgpEfPJbyUozp02n5nHgqvoWgQyXGG40tv4METTf0

Jancsák Csaba (2019). A személyes narratívák és a történelemtanítás értékvilága. In Kovács Gusztáv \& Lukács Ottilia (szerk.), Az elbeszélés ereje. Pécs: Pécsi Püspöki Hittudományi Főiskola. 7-22. ISBN 978-615-5579-25-7

Jenkins, K. (1991). Re-thinking history. London: Routledge. DOI: 10.4324/978020342686

Jordanova, L. (2000). History in Practice. London: Arnold.

Kojanitz László (2013). A történelmi gondolkodás fejlesztése. Iskolakultúra, 23(2), 28-47. http://epa. oszk.hu/00000/00011/00173/pdf/EPA00011_iskolakultura_2013_2_028-047.pdf

Kojanitz László szerk. (2018). A történelemtanítás megújítása - Kerekasztal-beszélgetés az EKE-OFIban. Történelemtanitás, (LIII) Új folyam IX(3-4) (november) http://www.folyoirat.tortenelemtanitas. hu/2018/11/ a-tortenelemtanitas-megujitasa-09-03-04/
Kölbl, K. (2015). Historical Consciousness in Germany: Concept, Implementation, Assessment. In Ercikan, K. \& Seixas, P. (szerk.), New directions in assessing historical thinking. London: Routledge. 17-29.

Körber, A (2018). An on line comment to Lévesque, S. (2018): Removing the "Past": Debates Over Official Sites of Memory. Public History Weekly, 6(29). DOI: 10.1515/phw-2018-12570

https://public-history-weekly.degruyter.com/6-201829/removing-past-official-memory/

Körber, A. (2011). German history didactics: from historical consciousness to historical competencies - and beyond? In Bierg, H., Lenz, C. \& Thortensen, E. (szerk.), Historicizing the Uses of the Past. Scandinavian Perspectives on History Culture. Historical Consciousness and Didactics of History Related to World War II. Bielefeld: Transcript. 145-164. DOI: 10.14361/transcript.9783839413258.145

Megill, A (1994). Jörn Rüsen's Theory of Historiography: Between Modernism and Rhetoric of Inquiry. History and Theory 31(1), 51. DOI: 10.2307/2505651

Lee, P. J. (2005). Putting principles into practice: Understanding history. In Donovan, M. S. \& Bransford, J. D. (szerk.), How Students Learn: History in the Classroom. Washington DC: National Academies Press. 85-86.

Lévesque, S. (2018). Removing the "Past": Debates Over Official Sites of Memory. Public History Weekly, 6(29). DOI: 10.1515/phw-2018-12570

Rüsen, J. (2006). Historical Consciousness: Narrative, Structure, Moral Function, and Ontogenetic Development. In Seixas, P. (szerk.), Theorizing Historical Consciousness. Toronto: University of Toronto Press.

Seixas, P. (2016). A History/Memory Matrix for History Education Public. History Weekly, February. DOI: $10.1515 / \mathrm{phw}-2016-5370$

https://public-history-weekly.degruyter.com/ 4-2016-6/a-historymemory-matrix-for-history-education/

van Boxtel, C., Grever, M. \& Klein, S. (2015). Heritage as a Resource for Enhancing and Assessing Historical Thinking: Reflections from the Netherlands. In Ercikan, K. \& Seixas, P. (szerk.), New directions in assessing historical thinking. Routledge. 40-51.

Wineburg, S. (2007). Unnatural and essential: the nature of historical thinking. Teaching History, 129, 6-11. 


\section{Absztrakt}

A történelemoktatás válságban van, és ez a válság összefügg az általános történelmi kultúra leépülésével. Miközben a történelemtanítás igyekszik továbbra is a történettudomány szemléletét és a történeti kutatások eredményeit közvetíteni, a mindennapi életben és a médiákban zajló viták tartalma és hangneme, az emberek történelmi múltról alkotott képe egyre jobban távolodik ettöl. A tanulmányomban azt mutatom be, hogy mik a történelemtanítás lehetséges szerepei egy olyan korszakban, amelyben egyoldalúan konstruált és egymással élesen szemben álló múltképek kezdik eluralni a közbeszédet, a médiát és a mindennapi gondolkodást. Ennek során felhasználom majd Peter Seixas e probléma értelmezéséhez készített modelljét, foglalkozom Jörn Rüsennek és Andreas Körbernek a történelmi tudat különböző szintjeiről és fejlődéséről kialakított koncepciójával, és azokkal a gondolatokkal is, amelyeket Peter J. Lee fogalmazott meg a történelemtanítás autonómiájának fontosságáról. 